\title{
The Role of Foreign Assistances in Realizing Human Development Goals (Case Study: Russia, US and China in Indonesia)
}

\author{
Fadra $^{1}$, B. A. Shiriaev ${ }^{2}$ and N. A. Tsvetkova ${ }^{3}$ \\ \{fadra@dsn.moestopo.ac.id', shiriaev@spbu.ru² and n.tsvetkova@spbu.ru $\left.{ }^{3}\right\}$ \\ ${ }^{1}$ Faculty of Social and Political Sciences, Universitas Prof. Dr. Moestopo (Beragama) \\ Jl. Hang Lekir 1, No. 8, Jakarta 10270, Indonesia. \\ ${ }^{2,3}$ Faculty of International Relations, St. Petersburg State University \\ Ulitsa Smolnogo 1/3, $8^{\text {th }}$ Entrance, St. Petersburg, 191060, Russian Federation
}

\begin{abstract}
This research aims to compare the financial aids of US, Russia and China in Human Development in Indonesia. The purpose of this analysis is how to understand the role of foreign assistances as one of financial sources for developing countries in realizing the Millennium Development Goal. The liberalism perspective is the appropriate approaches to explain the object of study. The used method in this paper is qualitative methods in testing the correlated variables. This study will focus on analyzing how big is the role of foreign assistances of US, Russia, and China in Indonesia. The findings of this research show that the US and China are still leading the role in financing Human Development Program in Indonesia in number of foreign assistance. Meanwhile, Russia has in common with US in educational program of giving scholarships, though Russia does not provide substantial financial assistance for Indonesia's human development programs. As a result, US foreign assistance is the biggest assistance in supporting Indonesia towards realization of Human Development goals. Originality of this research: the higher number of foreign assistance of donor country the faster developing country in realizing of human development goals.
\end{abstract}

Keywords: Sustainable human development, role of foreign assistances, US, Russia, China, Indonesia

\section{Introduction}

In 1990, the first Human Development Report from the United Nations Development Program (UNDP) introduced a new approach to advancing human welfare. Human development or the human development approach, which is about expanding the wealth of human life, not just the economic wealth in which humans live. This is a people-focused approach and their opportunities and choices. Education is one of the main crucial aspects of human development. This means, it is important in shaping human life and development. Based on World Bank statistic, universities in Indonesia has an important role to create quality human resources in regions [1].

Agree with what the Minister of Manpower Muhammad Hanif Dhakiri said, there are three main issues in Indonesia's Human Resources problems related to labor. First is quality, second quality and third is distribution. Some important things must be done to build Indonesian human resources are the first investment in demand-oriented, focused, massive and 
equal human resources. Second is leadership (government) to invite industries to get involved together and third to carry out labor reforms to balance the supply and demand of the workforce [2].

The above preliminary analysis strengthens our idea about the importance to study the role of foreign assistance of developed countries in enhancing human sustainable development in developing countries. The rest of the paper is to describe the scholarship of US government in Indonesia in more details.

\section{Method}

This research was conducted as a part of a qualitative study of International Relation dicipline. The document studies were carried out to complement the secondary data related to the completion of this research. The documents studied in this study are the research reports, journal articles, and literature that support the writing of this research.

\section{Literature Review}

In his work paper, Rock has described the role of the United States in building Indonesia after the reform era in the field of education. A difficult time for Indonesia where economic and political conditions are unstable. Changes in the reform era are considered a great opportunity for changes in the development system. This contributes to researchers in understanding the changing situation in Indonesia, and the role of US assistance in the transition [3].

Based on a 2013 USAID report on Investment in Indonesia, it shows that programs and strategies from the US Agency for International Development in 2014-2018 classified into 4 things, namely: Democratic governance, essential human services for the poorest and most vulnerable improved, global development priorities of advanced mutual interest, and collaborative achievement in science, technology, and innovation increased [4].

According to Latif Adam, investment in education is one of human capital. It illustrates how education can significantly increase human resources, for example in Indonesia. Building human capacity will guarantee the economic future of a country, and this benefits both donor countries and recipient countries [5]. To understand how is human capital concept implemented, Anne C. Campbell successfully described about the role of foreign aid or scholarship in building human development through its alumni. She tries to explain the role of graduates or alumni who receive scholarships in the formation of fellow graduate social networks. More precisely, this paper describes how this alumni network was formed by scholarships given by donor countries. And this network will act as a guardian of the interests between donor countries and recipient countries. In the world of work, this alumni network will prioritize its alma mater in maintaining business connectivity. Indirectly this is worth the investment for the donor country in the continuity of its business interests in the recipient country [6].

In an official report of the US Congress compiled by Curt Tarnoff and Marian L. Lawson, they described how US Congress approve the annual foreign assistance budget. One of them is allocated to education. The number, recipient country and purpose of assistance are stated and classified based on US priorities or interest. US assistance in terms of education in Indonesia is still a US priority in the context of the US mission and vision internationally which is in line with one of the UN's ideals, namely to create sustainable human resources (MDGs and towards SDGs [7]. Alan Dessoft describes the magnitude of the relationship between Indonesia and the US not only in terms of cooperation but also cultural closeness. 


\section{Results and Discussion}

According to US Foreign Assistance database, US is the largest contributor in the world, with the allocation of funds allocated to several fields, one of which is education. The amount of funds allocated for foreign aid in 2017 amounted to \$44,883,888,121 USD [8]. US assistance in bilateral cooperation in the development sector occupies the highest position in the composition of foreign aid, which is $37 \%$ of the total budget. Whereas for humanitarian assistance still occupies the third position after US military assistance in the world. This bilateral assistance is given to countries on a bilateral basis, state assistance to countries, for example the US to Indonesia. This is done by the US as a form of US participation and consistency in supporting the UN's ideals in the international, namely the Sustainable Development Goals. In 2016, foreign assistance is estimated to account for $4.2 \%$ of discretionary budget authority and $1.2 \%$ of total budget authority [9].

\subsection{Role of US Scholarship in Building Human Development in Indonesia 4.1.1. Educational Provider}

The United States will commit more than $\$ 165$ million over five years to support the Higher Education Partnership to achieve common goals in higher education [10]. The main priority of the United States in Indonesia is to encourage Indonesian students to study in the United States. The Department of Foreign Affairs has increased funds to $\$ 4.5$ million annually for English language training, student consulting services, and other exchanges. The United States also increases the profile of US higher education institutions through education outreach to Indonesians. Fifty-six US higher education institutions participated in this mission, attracting thousands of prospective Indonesian students and their families. The Education USA Fair from the Fulbright Commission brought 45 additional universities to Indonesia to recruit students. Two educational exhibitions attract more than 20,000 people. US has more than 15 types of scholarship program in Indonesia. With such a program scheme, only US has the most variety scholarship programs in building human resources [11].

\subsubsection{Partner of Government in Building Capacity}

Efforts made by the government through various educational program packages as the application of the $20 \%$ education budget from the APBN, allocations in regions that are still very minimal compared to the needs of the community. Programs made by the government only approve patchy (incremental) and unsustainable programs. The government plays an important role in improving the quality of education for Indonesian children, the initial role needed and the minimum infrastructure of decent office buildings, to reach various other educational support facilities. US is Indonesia's partner in developing natural resources with education, training and infrastructure development programs [12]. The USAID scholarship program provides opportunities for Indonesian scholars to obtain advanced academic degrees in the US and Indonesia. Scholars are supported by USAID studies in the fields of law, economics, public policy, political science, public administration, environment, health and education. Scholars develop the skills and expertise needed to overcome global challenges. Since the late 1950s, more than 4,000 Indonesians have received USAID scholarships in the US and Indonesian universities, and tens of thousands of Indonesians have attended short-term training programs [13]. The USAID scholarship program has provided 248 Indonesians with education, 1,280 Indonesians the opportunity to receive short-term training, and 1,750 poor and disabled people receive skills training [14]. 


\subsubsection{Academic Connector}

LeRoy Bennett said that in international organizations there is an organizational structure to achieve its goals. If these structures have functioned, the organization has carried out its role. Parallel to the state, international organizations can carry out and have a number of important roles, namely: First, provide a means of cooperation among countries in various fields, where such cooperation provides benefits for most or all of its members. Aside from being a place where decisions about cooperation are made, it also provides administrative tools to translate these decisions into action. Second, provide various lines of communication between governments of countries, so that it can be explored and will facilitate access if problems arise [15]. Institutions such as USINDO, USAID, AMINEF are specialized institutions that play an important role in connecting and collaborating between USIndonesian academic institutions (universities and institutes). With this institution, this activity directly supports what is in the interests of the Indonesian Ministry of Education, where the Government of Indonesia under the Ministry of Education encourages Indonesian universities, both public and private, to collaborate with universities in other countries. This is intended to provide information exchange and development of knowledge between universities. With this collaboration, it is expected that the quality of Indonesian universities will be better so that it can improve the quality of Indonesia's human resources with education.

\subsubsection{People-to-People Contact}

The relationship between Indonesia and the US not only in terms of cooperation but also cultural closeness. The number of high-ranking officials and smart people graduating from universities in the US, and how many Indonesians who later settled and worked in the US, and vice versa. Indonesia has always been a US priority, many things cannot be denied that Indonesia is a large country and a regional strategic partner for anyone. The number of US and Indonesian universities collaborates with more than 100 universities, both in academic and cultural fields. Indonesia is currently preparing for human development, this is realized by the increasing education budget allocation. The US has also built more than 50 years of Indonesia with its government budget and private institutions or companies [16].

USINDO is the only official and most influential institution in the field of education and culture. The closeness of the two countries is not only achieved by official government cooperation, but also with non-formal communication that has deep psychological strength. Both people are getting to know each other through cultural communication created not only in the form of festivals or cultural ceremonies, but the introduction in the form of discussion and direct communication that occurs among many levels of society, namely at the level of youth groups, educators, academics, politics and government, and art. This is very effective in bringing the psychology of the two nations closer together. Through culture and education USINDO has succeeded in increasing intellectuals of Indonesian students, and even strengthening contact between US-Indonesian people, or what known as people-to-people contact. This proves the role of US scholarships given by one USINDO institution that has encouraged what is called Human Development in Indonesia, both formally and non-formally.

\subsubsection{Employment Provider}

Stephen Kosack and Jennifer Tobin explain how important foreign assistance is in the sustainability of a country's development. Foreign aid, scholarship or investment is a form of investment that leads to the concept of human capital. Humans as the economic capital of a country, where the sustainability of economic growth will be determined by the quality of its 
human resources in the management of state assets. Educational investment is a long-term investment that is currently important for both developed and developing countries. The flow of foreign capital most often comes in two forms: foreign aid, and foreign direct investment (FDI) has long been considered preferred by both, especially by the United States. Both require capital growth for their country, donor countries need business and market sustainability in the recipient country, while recipient countries need human development for future economic growth [17].

The US government does not provide military or humanitarian assistance just like that without any political or economic goals. The human development and infrastructure assistance funds poured through USAID and others are intended not only for Indonesia's development, but also must be in line with US interests. Tarnoff dan Lawson emphasized that both USAID and the Department of Foreign Affairs have promoted the use of public-private partnerships, where private entities such as corporations and foundations are contributing partners, not paid implementers, in situations where business interests and development goals coincide [18].

The number of US companies in Indonesia is more than 70 well-known companies. Here are examples of companies from 20 companies with the largest shares in the US in 2018: Apple, Berkshire Hathaway, JP Morgan Chase, ExxonMobil, Microsoft [19]. Imagine how much this company is in Indonesia, and how much skilled labor is needed to run their business in Indonesia. This is of great value to the economy of the Indonesian government and the people of Indonesia [20]. These number of companies are also explained by Campbell, that alumni network will prioritize its alma mater in maintaining business connectivity. Indirectly this is worth the investment for the donor country in the continuity of its business interests in the recipient country [21].

To close this section, we conclude that the US scholarship funding has an important role in the development of human resources in Indonesia. This role is implemented in many programs and types of scholarships. The US-run role is in line with the political and business interests of US companies in Indonesia. This role is also a form of social responsibility of US capitalist countries to developing countries in the world, where US business is developing.

\section{Closing Remarks}

The US Funding Agency is more than 6 major institutions including MCC and USAID. The number of Indonesian students who have graduated from US education has more than 6000 graduates since the 1950s. Not to mention added with the diaspora of Indonesian citizens in the US who work and assimilate through marriage. The US is the only country with the most Indonesian student graduates. This is very significant not only for the Indonesian government, but also very meaningful for improving the lives of Indonesian people. US graduate students certainly have a great opportunity to be able to get higher education and employment in the future. This is influenced by two main factors: the Indonesian mindset about the value of high quality education in the US; and the large number of agencies, NGOs, official representative bodies, and large US companies operating in Indonesia. The second factor is what makes many US graduates recruited to work in US companies or agencies. In addition to language, psychological closeness is certainly the basis of the recruitment. US graduate students certainly understand more about US business mindset and interests. Although not all US companies only recruit US graduates, but most of the human resources placed to occupy these important positions, some representatives are Indonesians with US education graduates. We close this presentation with a simple word that scholarships are the 
best help the US can provide to build human resources and improve the economy of Indonesia.

\section{Acknowledgment}

The authors would like to address our deep gratitude to Universitas Prof. Dr. Moestopo (Beragama) for providing conference facilities to the first author.

\section{References}

[1]. "Putting Higher Education to Work: The Skills and Research for Growth in East Asia." World Bank, 2011.

[2]. "Tiga Isu Utama SDM Indonesia dalam Angkatan Kerja.” Kementerian Keuangan Indonesia, 2018.

[3]. Rock, M. T. "The Politics of Development Policy and Development Policy Reform in New Order Indonesia." The William Davidson Institute, 2003.

[4]. "Investing in indonesia: a stronger indonesia advancing national and global development. usaid strategy for indonesia." USAID, 2017.

[5]. Adam, L., \& Siwage. "Improving human capital through better education to support indonesia economic development and finance in indonesia." 2015.

[6]. Campbell, A. C. "International scholarship graduates influencing social and economic development at home: the role of alumni networks in georgia and moldova. current issues in comparative education," 2016.

[7]. Tarnoff, Curt; Lawson M. "Foreign Aid: An Introduction To US Programs And Policy." Congressional Research Service, 2018.

[8]. "Map of Foreign Assistance of Worldwide 2017." Foreignassistance.gov, 2017.

[9]. Tarnoff, Curt; Lawson M. "Foreign Aid: An Introduction To US Programs And Policy." Congressional Research Service, 2018.

[10]. "Fact sheet US Indonesia education partnership." US Embassy\& consulates in indonesia, 2017.

[11]. "Investing in indonesia: a stronger indonesia advancing national and global development. usaid strategy for indonesia." USAID, 2017.

[12]. Donovan, J. "USA-One of indonesian outstanding partners in promoting higher education,science, technology and inovation development." RISTEKDIKTI, 2017.

[13]. "Investing in indonesia: a stronger indonesia advancing national and global development. usaid strategy for indonesia." USAID, 2017.

[14]. "Investing in indonesia: a stronger indonesia advancing national and global development. usaid strategy for indonesia." USAID, 2017.

[15]. Backman., Carl W. "Role Theory and International Relations: A Commentary and Extension.” International Studies Quarterly. Vol. 14, No. 3 (Sep., 1970), pp. 310-319. DOI: $10.2307 / 3013585$.

[16]. Dessoff, A. "Building Indonesia and Partnerships The United States," 2011.

[17]. Kosack, S., \& Tobin, J. "Funding Self-Sustaining Development: The Role of Aid, FDI and Goverment in Economic Success." 2016.

[18]. Tarnoff, Curt; Lawson M. "Foreign Aid: An Introduction To US Programs And Policy." Congressional Research Service, 2018.

[19]. Melani, A. "Mengintip jajaran 20 perusahaan raksasa di AS.” Liputan 6, 2018.

[20]. [20] Melani, A. "Mengintip jajaran 20 perusahaan raksasa di AS." Liputan 6, 2018. 
